This author not long ago had occasion to observe in two case. of Graves' disease an increase in the exophthalmos after acute catarrh of the nose.

Other authors (M. Schmidt, B. Fraenkel, etc.) in their cases have stated only the fact of the undoubtedly favourable influence of nasal operations upon the symptoms of Graves' disease, but without entering into an explanation of this fact.

\title{
REFERENCES.
}

(1) “Zur operativen Therapie der Basedow'schen Krankheit," Deut. med. Woch.. No. 2.

(2) Reported in Hoffmann's paper, "Beeinflussung der Basedow symptome von der Nase aus," Monats. $f$. Ohrenheilk., No. 9, 1910.

(3) "Heilung eines Morbus Basedowii durch Besserung eines Nasenleidens," Berl. klin. Woch., No. 43.

(4) Berl. klin. Woch., 1888.

(5) Brit. med. Journ., 1888

(6) "Le malattie della cavita dei seni nasali studiati come momenti potegenetici di parecchie malattie dell' apparato oculare, del gozzo esoftalmico, di" alcune malattie delle pelle del naso e della faccie," 1889.

(7) "Symptomatologie und Therapie der nasogenen Reflexneurosen und Organerkrankungen, etc.," Lorgnitz, 1900.

(8) Deutsch. med. Woch., 1892.

(9) “Zur Beantwortung der Frage, Wann können intranasale Eingriffe beim Morbus Basedowii gerechtfertigt sein?" Wien. med. Woch., 1892, No. 42.

(10) Mentioned in the above Hoffmann's paper.

(11) "Graves' Disease and Nasal Polypi," Brit. Med. Journ., November 17.

(12) Loc. cit. (No. 5).

(13) "Ueber Beeinflussung des Basedowexophthalmus von der Nase aus," Miinch. med. Woch., No. 44, 1910.

(14) Nowiny Lekarskie, No. 7.

(15) “Unilateral Polypi and Incomplete Graves' Disease after Removal of Nasal Polypi," Brit. Med. Journ., 1889, April 20.

(16) In the discussion on the above paper.

\section{THE TEACHING OF OTO-RHINO-LARYNGOLOGY IN FRANCE.}

By Dr. Georges Gellé, Oto-Laryngologist-in-Chief to the Ophthalmological Clinic of the Faculty of Medicine in Paris ; President of the French Oto-RhinoLaryngological Society.

Medical education in France is vested in the Faculties of the seven Universities of Paris, Montpellier, Nancy, Lyons, Bordeaux, lille (where there is also an extra-mural Faculty), and Toulouse; in four schools with complete curricula (Marseilles, Nantes, Alger and Rennes) ; and in twelve preparatory schools.

In none of these centres is there a University Chair of oto-rhino- 
laryngology, this branch of medicine being less favourably treated than ophthalmology, psychiatry and dermatology, each of which is represented in all the Universities by a titulary Professor.

All, or nearly all, existing French specialists owe their education to gratuitous instruction either in private clinics such as those of Lubet-Barbon and Martin, of Luc, Bonlay, etc., or in hospital clinics attached to the municipalities, like those of Gougenheim and Lermoyez in Paris, of Garel in Lyons, etc., or in special consultation departments in the clinics of certain professors such as Gellé, sen., who was attached to Charcot's department at the Salpétrière, and myself in the clinic of the Professor of Ophthalmology, M. de Lapersonne. This teaching is all voluntary and in no sense official, and at the examinations students are examined in laryngology by professors of internal medicine and in otology and rhinology by professors of external pathology.

Nowhere in France is any evidence demanded as to the special attainments of medical practitioners. The specialist is self-created. It must, however, be noted that, since May, 1907, the French Otorhino-laryngological Society has stipulated that those who desire to become members must give eridence that they have studied otorhino-laryngology for twelve months in one or more special clinics, miversity or extra-mural (libres), either in France or abroad. Further, they must show, at the time of application, that they have been engaged for a year in the exclusive practice of the speciality in one or two fixed residences in France. Two sponsors are required to guarantee, on their own responsibility, the validity of the candidate's declarations relative to the aforesaid conditions of tndy and practice.

As a result of the pressure of public opinion sensible progress has for some time been manifest, and in a few months perhaps we whall have the first full professor of oto-rhino-laryngology in France. To all appearance it is one of the provincial universities which will be the first to set the good example. Indeed, in Bordeaux ince 1904, and in Montpellier and Lyons since 1908, the instruction has been in the hands of a Professeur Adjoint (a title corresponding to the German "Professor Extraordinary"). In Nancy since 1901 and in Paris since 1896 it has been given by a Lecturer (chargí de .nurs). Later on we shall examine the arrangements which these two universities have made for teaching our special subjects.

We proceed now to review the teaching of oto-rhino-laryngology in each of our University faculties.

(1) The Faculty of Medicine of Paris.-Apparently it was in 
1896 when Dr. Castex was first appointed lecturer, on the proposal of Brouardel, the doyen at that time. At present he has three assistants. Students desiring to take out the course enrol themselves at the secretariat of the Faculty and pay a fee of fifty francs a month. They camnot enrol for less than a month, and the courses: do not qualify for graduation ("ils [i.e. the students] ne sont pa. consilér's comme stagiaires").

Pupils and patients are admitted to the clinic, where instruction is given (Ecole pratique, 10 rue Racine) daily from three to five o'clock by the chef de clinique and his assistants. But the detailed arrangements are as follows: An advanced class is held both in winter and in summer in the Amphithéatre Cruveilhier; on 'Tuesdays, 'Thursdays, and Saturdays a gratuitous course lasting three months is given by the professor; in the spring a course at the clinic is held; and lastly, there is a vacation course in September conducted by the assistants.

Unfortunately there are no beds attached to the clinic, and major operations have to be performed at a special Maison de Santr, where the necessitous poor are treated free. Since the date of its foundation until December 31st, 1911, 309,199 consultations had been held, 14,281 operations performed, and 2243 pupils had attended the clinic.

So much for the official tuition. In addition there are several other very important centres, namely, that of Lermoyez at the hospital St. Antoine, that of Sebileau at the Lariboisière, and lastly, that of Lombard at the Laënnec. All these clinics possess berls and operating theatres, and the classes organised by the chiefs have a high reputation and are much sought after. These clinics are under the administration of the Municipality of Paris.

It should be noted that for several years past this municipal administration has instituted a competition of oto-rhino-laryngologists by which candidates are chosen to fill the vacancies in the hospitals. There are four of these-Lombard, Bourgeois, Lemaitre and Grivot, of whom only the first has a hospital appointment. With regard to Lermogez, he is physician to the hospital while Sebileau is surgeon to the hospital, but their work is special and equivalent to that of oto-laryngologist to the hospital.

In several of the university clinics-neurology, dermatology, etc.- - there is an oto-rhino-laryngologist. This is the post which I occupy at the Hôtel Dieu in the ophthalmological clinic of Professor de Lapersonne. During May and Jume an advanced course (contrs de perfectionnement) is held at which I teach rhinology and otology 
in relation to orbito-ocular affections. The teaching is followed by practical exercises on the cadaver, the different operations on the sinuses being performed by the pupils. The fee for the course is 100 francs. It is especially arranged for the future French ophthalmologists who intend to settle in the provinces, where ophthalmology and our own speciality must be practised side by side if the practitioner hopes to make a living.

Thus, when we consider that in addition to this teaching there are at the disposal of the student the handsome and well-known private clinics we mentioned at the beginning of this article, it is obvious that a student can continue his special training for as long as he pleases, and it is not surprising to find that foreign students attending the courses are as numerous as ever they were. Otficial recognition is all that is wanting, and it camot be much longer delayed.

(2) The Faculty of Medicine of Nancy.--Special instruction was initiated in Nancy on November 1, 1897, by Dr. P. Jacques, Professeur Adjoint, in a course which is gratuitous. In 1901 it was officially recognised by the inauguration of a lectureship with a modest stipend from the University funds.

This clinic is provided with twenty-seven beds and admits: from 3000 to 4000 patients anmually. The staff consists of a chief faid by the University, an interne supported by the hospital administration, and two externes. The classes are intended for fourth or fifth year students of medicine and they are obliged to take "nt a three months' course. Dental students attend the course as part of their training in stomatology. Clinical demonstrations are wiven on Mondays and Fridays from ten to twelve, and a weekly lecture is delivered on Wednesdays. The class is free to students. With the help of one of his assistants Jacques conducts special practical classes for the residents in the hospital, and these are also free. For the more advanced courses, two in number, for loctors and post-graduate students a fee is charged.

(3) The Faculty of Medicine of Lille.--In Lille there is no recoguised course of teaching, but a free class for fourth-year students is carried on by Prof. Gaudier during the winter session. It "onsists of an out-patient department which is an adjunct to the urgical clinic of Prof. Gaudier. Minor operations are performed in the out-patient room and major operations in the hospital. I understand that Prof. Gaudier is the first who has asked candidates in the clinical examinations to examine patients suffering from simple special diseases. His class, though not compulsory, is well attenrled. 
In the Catholic Faculty of Medicine at Lille there has been an oto-rhino-laryngological out-patient department since 1887, under. the care of Dr. Lavrand. An interne is attached to the clinic, but it has no free beds. Classes remain optional, and there is no regular advanced course.

(4) The Fuculty of Medicine of Toulouse.-There is no recognised course of teaching in Tonlouse. Dr. Escat's post is like that formerly held by my father at the Salpétrière, namely, an official out-patient department in another clinic-in this case that of dermato-syphilology. 'This is a "provisional" arrangement which has now been in existence for eighteen years. Since 1894 Escat has every year conducted a gratuitous course of instruction, a course which is recognised by the Council of the University. 'I'he state of matters in 'Toulouse is lamentable, and it is astonishing that in France conditions like these should have lasted for such a length of time.

(5) The Faculty of Medicine of Bordeaux.-The teaching of oto-rhino-laryngology in Bordeaux is carried on as follows: First of all there is an official (State) instruction consisting of outpatient consultations held in premises belonging to the University. In addition, a grant of sixteen beds has been made to the department by the hospital administration of Bordeaux.

The clinic is under the control of Prof. Moure, supported by an assistant paid by the State, and assisted by an interne and externes and medical students. These last are students who, in their fourth year, are distributed among the various special clinics (ophthalmology, dermatology, urology, oto-rhinology).

Moure, if my memory is correct, began in 1880 with a free instruction, which was the first special clinic in the provinces. But it is only since 1890 that he has been officially recognised, at first as Lecturer (chargé de cours), and then, since 1904, as Professeur Adjoint.

(6) The Faculty of Medicine of Montpellier.-In 1907, Mouret, then supernumerary professor of anatomy, was given a clinical course in oto-rhino-laryngology with an out-patient department at the general hospital. Next, he was given some beds to be shared with urology. In 1908 he was appointed Professeur Adjoint, and since then further advances fall to be recorded in the shape of twenty-two beds. But the instrumental material is still scanty, and there is neither a chef de clinique nor an interne-only a couple of externes. The course qualifies for graduation, and at the end of each term the professor grants a certificate testifying 
that the pupil has diligently followed the course. Refusal of the certificate is equivalent to the absence of a class certificate of attendance.

(7) The Faculty of Medicine of Lyons.-In Lyons there was no recognised teaching prior to 1898. Garel and Lannois each arried on gratuitious out-patient clinics and conducted free courses of instruction. In 1898 Lannois became lecturer, and then in 1908 Professe? Adjoint. A portion of Lannois' clinic having been ceded by the Lyons hospital administration in order to establish a university clinic, it now comprises a large hall for consultations, a lecture room, an operating theatre and eighteen beds. There is an assistant of the clinic-paid by the universityand an interne and an externe dependent upon the hospitals.

The courses of instruction, which are free, are open to third ind fourth years' students and to pupils of the School of Military Medicine.

In addition to this fine clinic there are also in Lyons an outpatient clinic under Dr. Collet and another under Dr. Garel, but neither of these is officially recognised.

Thus it is seen that the development, after some years of "estraint, is at last taking shape, so that at the present day in come of the universities-Bordeaux, Lyons, Nancy-well-estabished and well-equipped clinics and courses of instruction have ren installed, all that is absent being the university title of !rofessor.

This further advance is opposed, here and there, by certain versonal influences, and everywhere by financial considerations. Cor the French Republic, which lavishes money without stint on lementary education-with, often, but a mediocre result-belaves towards higher education in the most miserly fashion.

(D. M., Trans.) 